\title{
Synthesis and Characterization of Five-Coordinate Gallium and Indium Complexes Stabilized by Tridentate, Substituted Pyrrole Ligands
}

\author{
Pei-Cheng Kuo, ${ }^{\text {[a] }}$ Jui-Hsien Huang, ${ }^{* \text { [a] }}$ Chen-Hsiung Hung, ${ }^{\text {[a] }}$ Gene-Hsiang Lee,${ }^{[b]}$ and \\ Shie-Ming Peng ${ }^{[b]}$
}

Keywords: Gallium / Indium / N ligands / Bridging ligands

Five-coordinate gallium and indium complexes stabilized by tridentate, substituted pyrrole ligands have been synthesized and characterized. The reaction of $\mathrm{MCl}_{3}$ with 1 equiv. of $\mathrm{Li}\left[\mathrm{NC}_{4} \mathrm{H}_{2}\left(\mathrm{CH}_{2} \mathrm{NMe}_{2}\right)_{2}-2,5\right]$ in diethyl ether affords $\left[\left\{\mathrm{NC}_{4} \mathrm{H}_{2}\left(\mathrm{CH}_{2} \mathrm{NMe}_{2}\right)_{2}-2,5\right\} \mathrm{MCl}_{2}\right][\mathrm{M}=\mathrm{Ga}(1)$, In (2)] in high yield. Reaction of $\mathbf{1}$ with 2 equiv. of MeLi in diethyl ether at $-78{ }^{\circ} \mathrm{C}$ followed by heating to reflux for $30 \mathrm{~min}$ affords the alkylated product $\left[\left\{\mathrm{NC}_{4} \mathrm{H}_{2}\left(\mathrm{CH}_{2} \mathrm{NMe}_{2}\right)_{2}-2,5\right\} \mathrm{GaMe}_{2}\right]$ (3). Sim-

\section{Introduction}

Lewis acids catalyze a wide range of reactions. The reactivity and selectivity of these reactions are often related to the Lewis acid's electronic and steric properties. ${ }^{[1]}$ Among the Lewis acid catalysts derived from group-13 metals, those of aluminum are well known for serving as catalysts in organic synthesis, and more recently for polymerization reactions. ${ }^{[2-4]}$ The number of metal complexes reported, however, declines upon descending the group from aluminum to indium. Indium-mediated organometallic reactions have received considerable attention recently, due to their tolerance of polar solvents, including water. ${ }^{[5-11]}$ Lewis acidic indium complexes are dominated by a low coordination number at the metal center (three or four) ${ }^{[12-14]}$ but a few complexes of higher coordination number (five and six) have been reported. ${ }^{15-21]}$

We have been interested in the chemistry of group$13^{[22-23]}$ and early transition metal complexes ${ }^{[24-25]}$ stabilized by bi- or tridentate substituted pyrrole ligands. ${ }^{[26-27]}$ These complexes are Lewis acids with the potential to serve as catalysts in organic synthesis or for the polymerization of olefins. We report here the syntheses, intramolecular rearrangement, and X-ray crystal structures of Ga and In complexes.

[a] Department of Chemistry, National Changhua University of Education,

Changhua 50058, Taiwan

E-mail: juihuang@cc.ncue.edu.tw

[b] Department of Chemistry and Instrumentation Center, National Taiwan University,

Taipei 10764, Taiwan ilarly, the reaction of $\mathbf{2}$ with 2 equiv. of MeLi or $n \mathrm{BuLi}$ affords the dialkylated complexes $\mathbf{4}$ and 5, respectively. Complex 2 is a strong Lewis acid which readily absorbs $\mathrm{H}_{2} \mathrm{O}$ forming $\left[\left\{\left[\mathrm{C}_{4} \mathrm{H}_{2} \mathrm{~N}\left(\mathrm{CH}_{2} \mathrm{NMe}_{2}\right)_{2}-2,5\right] \mathrm{InCl}_{2}\right\}_{2}\left(\mu-\mathrm{OH}_{2}\right)\right]$ (6). Complexes 3, 4, and 6 have been characterized by X-ray crystallography.

(ㄷ Wiley-VCH Verlag GmbH \& Co. KGaA, 69451 Weinheim, Germany, 2003)

\section{Results and Discussion}

\section{Synthesis and Characterization}

Reaction of $\mathrm{Li}\left[\mathrm{NC}_{4} \mathrm{H}_{2}\left(\mathrm{CH}_{2} \mathrm{NMe}_{2}\right)_{2}-2,5\right]$ with $\mathrm{MCl}_{3}(\mathrm{M}=$ $\mathrm{Ga}, \mathrm{In})$ in diethyl ether affords $\left[\left\{\mathrm{NC}_{4} \mathrm{H}_{2}\left(\mathrm{CH}_{2} \mathrm{NMe}_{2}\right)_{2}\right.\right.$ $\left.2,5\} \mathrm{MCl}_{2}\right][\mathrm{M}=\mathrm{Ga}(\mathbf{1})$, In (2)] in yields of 98 and $81 \%$, respectively (Scheme 1). However, suitable crystals of complexes 1 and 2 could not be obtained. The ${ }^{1} \mathrm{H}$ and ${ }^{13} \mathrm{C}$ NMR spectra of both $\mathbf{1}$ and $\mathbf{2}$ show the signals of one type of $\mathrm{CH}_{2}$ and $\mathrm{NMe}_{2}$ units at $\delta \approx 3.6$ and $2.5 \mathrm{ppm}$, respectively, which are consistent with symmetrical structures.

Reaction of complex 1 with 2 equiv. of $1.6 \mathrm{M}$ methyllithium in diethyl ether solution at $-78{ }^{\circ} \mathrm{C}$ followed by heating to reflux for $30 \mathrm{~min}$ afforded the dimethylgallium complex $\left[\left\{\mathrm{NC}_{4} \mathrm{H}_{2}\left(\mathrm{CH}_{2} \mathrm{NMe}_{2}\right)_{2}-2,5\right\} \mathrm{GaMe}_{2}\right]$ (3) in $75 \%$ yield. The ${ }^{1} \mathrm{H}$ NMR spectrum of 3 shows signals of one set of $\mathrm{CH}_{2}, \mathrm{NMe}_{2}$, and $\mathrm{GaMe}$ units at $\delta=3.47,2.29$, and -0.37 ppm, respectively.

Similarly, treatment of 2 with 2 equiv. of $\mathrm{MeLi}$ or $n \mathrm{BuLi}$ in a diethyl ether solution at $-78^{\circ} \mathrm{C}$, allowing to warm to room temperature, and then heating to reflux for $30 \mathrm{~min}$ generated the pure dimethyl complex $\mathbf{4}$ and the dibutyl complex 5 in yields of 61 and $65 \%$, respectively. Complexes $\mathbf{3}, \mathbf{4}$, and $\mathbf{5}$ are thermally robust and show no decomposition upon heating in toluene at $100{ }^{\circ} \mathrm{C}$ for over $12 \mathrm{~h}$.

Complex $\mathbf{2}$ is very Lewis acidic and reacts readily with moisture upon exposure to air. During recrystallization of 2 from a toluene solution at $-20^{\circ} \mathrm{C}$, the Schlenk flask was occasionally opened to air resulting in the deposition of the water-bridged complex $\left[\left\{\left[\mathrm{C}_{4} \mathrm{H}_{2} \mathrm{~N}\left(\mathrm{CH}_{2} \mathrm{NMe}_{2}\right)_{2}\right.\right.\right.$-2,5]$\left.\left.\mathrm{InCl}_{2}\right\}_{2}\left(\mu-\mathrm{OH}_{2}\right)\right](\mathbf{6})$. The procedure was carried out several times in both toluene and diethyl ether, and the same result was obtained. Attempts to let 2 react with 0.5 equiv. of $\mathrm{H}_{2} \mathrm{O}$ 


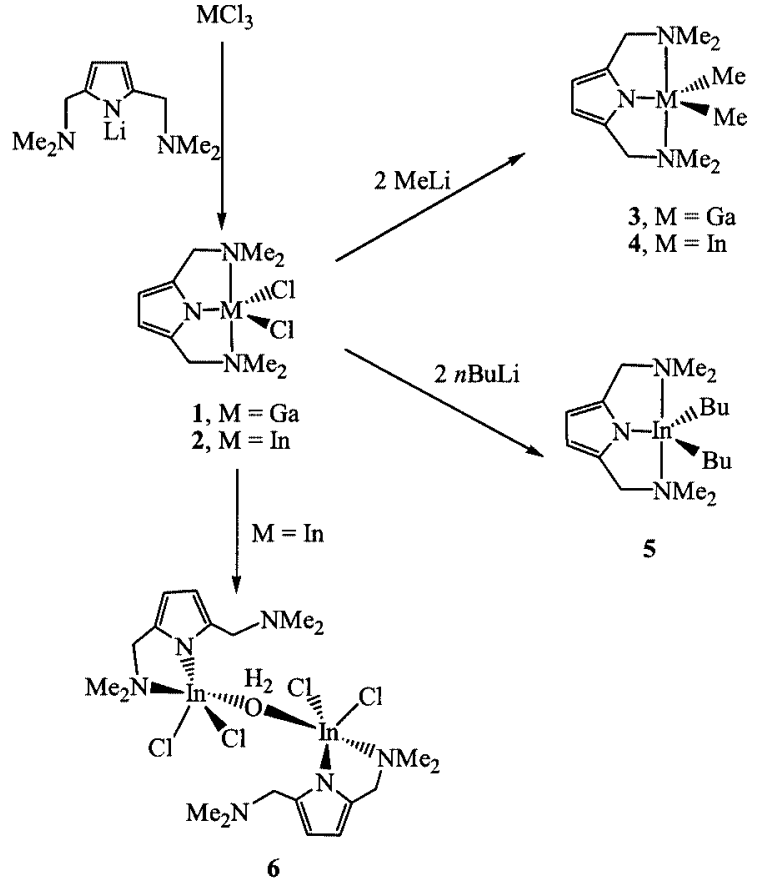

Scheme 1

in either toluene or diethyl ether afforded a mixture, from which only a small amount of $\mathbf{6}$ was isolated. Similarly, diffusion of $\mathrm{H}_{2} \mathrm{O}$ vapor into a toluene solution of 2 yielded the same results. The ${ }^{1} \mathrm{H}$ NMR spectrum of 6 in $\mathrm{CD}_{2} \mathrm{Cl}_{2}$ at room temperature indicates an asymmetric arrangement, which is consistent with the X-ray crystal structure (vide infra). Complex 6 gives rise to three methyl resonances for the two $\mathrm{NMe}_{2}$ units at $\delta=2.50,2.59$, and $2.84 \mathrm{ppm}$ in the ratio of 1:1:2. Four doublets for the two $A B$ systems of the $\mathrm{CH}_{2} \mathrm{~N}$ units were observed at $\delta=3.16,3.70,4.56$, and 4.72 ppm in the ratio of 1:1:1:1. Selective homonuclear decoupling of the ${ }^{1} \mathrm{H}$ NMR spectrum of 6 revealed that one $\mathrm{AB}$ pattern of a $\mathrm{CH}_{2} \mathrm{~N}$ unit gives rise to the resonances at $\delta=$ 3.16 and $4.56 \mathrm{ppm}$ while the other unit can be attributed to the resonances at $\delta=3.70$ and $4.72 \mathrm{ppm}$.

\section{Solid-State Structures of Complexes 3, 4, and 6}

Crystals of $\mathbf{3}$ suitable for X-ray structure determination were obtained from a saturated diethyl ether solution stored at $-20^{\circ} \mathrm{C}$. Crystals of $\mathbf{4}$ were obtained by sublimation from a flask in the glove box under nitrogen. Details of the data collections for $\mathbf{3}$ and $\mathbf{4}$ are summarized in Table 2 with selected bond lengths and angles listed in Table 1. The ORTEP diagram of complex 3 is depicted in Figure 1. The gallium atom is surrounded by two methyl groups and three nitrogen atoms of the tridentate pyrrolyl ligand, $\left[\mathrm{NC}_{4} \mathrm{H}_{2}\left(\mathrm{CH}_{2} \mathrm{NMe}_{2}\right)_{2}-2,5\right]$, forming a distorted trigonal-bipyramidal structure. The tridentate pyrrolyl ligand is arranged at the meridional positions, with the pyrrolyl nitrogen atom occupying the equatorial position and the two $\mathrm{NMe}_{2}$ units occupying the axial positions. The axial $\mathrm{N}(1)-\mathrm{Ga}-\mathrm{N}(3)$ angle of $146.68(6)^{\circ}$ deviates from linearity

Table 1. Selected bond lengths $[\AA]$ and angles $\left[{ }^{\circ}\right]$ for compounds $\mathbf{3}, \mathbf{4}$, and $\mathbf{6}$

3

\begin{tabular}{|c|c|c|c|c|c|c|c|}
\hline $\mathrm{Ga}-\mathrm{N}(2)$ & $1.920(2)$ & $\mathrm{Ga}-\mathrm{C}(2)$ & $1.953(2)$ & $\mathrm{Ga}-\mathrm{C}(1)$ & $1.969(2)$ & $\mathrm{Ga}-\mathrm{N}(1)$ & $2.307(2)$ \\
\hline $\mathrm{Ga}-\mathrm{N}(3)$ & $2.736(2)$ & & & & & & \\
\hline $\mathrm{N}(2)-\mathrm{Ga}-\mathrm{C}(2)$ & $121.38(10)$ & $\mathrm{N}(2)-\mathrm{Ga}-\mathrm{C}(1)$ & $114.36(9)$ & $\mathrm{C}(2)-\mathrm{Ga}-\mathrm{C}(1)$ & $123.10(11)$ & $\mathrm{N}(2)-\mathrm{Ga}-\mathrm{N}(1)$ & $77.13(7)$ \\
\hline $\mathrm{C}(2)-\mathrm{Ga}-\mathrm{N}(1)$ & $102.57(9)$ & $\mathrm{C}(1)-\mathrm{Ga}-\mathrm{N}(1)$ & $99.66(9)$ & $\mathrm{N}(2)-\mathrm{Ga}-\mathrm{N}(3)$ & $69.92(6)$ & $\mathrm{C}(2)-\mathrm{Ga}-\mathrm{N}(3)$ & $90.63(8)$ \\
\hline $\mathrm{C}(1)-\mathrm{Ga}-\mathrm{N}(3)$ & $98.27(9)$ & $\mathrm{N}(1)-\mathrm{Ga}-\mathrm{N}(3)$ & $146.68(6)$ & & & & \\
\hline
\end{tabular}

4

\begin{tabular}{|c|c|c|c|c|c|c|c|}
\hline $\operatorname{In}(1)-\mathrm{N}(2)$ & $2.108(5)$ & $\operatorname{In}(1)-C(2)$ & $2.173(6)$ & $\operatorname{In}(1)-C(1)$ & $2.187(6)$ & $\operatorname{In}(1)-\mathrm{N}(1)$ & $2.519(5)$ \\
\hline $\operatorname{In}(1)-N(3)$ & $2.681(6)$ & $\operatorname{In}(2)-N(5)$ & $2.117(5)$ & $\operatorname{In}(2)-C(14)$ & $2.087(7)$ & $\operatorname{In}(2)-C(13)$ & $2.161(6)$ \\
\hline $\operatorname{In}(2)-N(4)$ & $2.516(6)$ & $\operatorname{In}(2)-N(6)$ & $2.670(6)$ & & & & \\
\hline $\mathrm{N}(2)-\operatorname{In}(1)-\mathrm{C}(2)$ & $113.1(2)$ & $\mathrm{N}(2)-\operatorname{In}(1)-\mathrm{C}(1)$ & $121.2(2)$ & $\mathrm{C}(2)-\operatorname{In}(1)-\mathrm{C}(1)$ & $124.6(3)$ & $\mathrm{N}(2)-\operatorname{In}(1)-\mathrm{N}(1)$ & $71.9(2)$ \\
\hline $\mathrm{C}(2)-\operatorname{In}(1)-\mathrm{N}(1)$ & $105.4(2)$ & $\mathrm{C}(1)-\operatorname{In}(1)-\mathrm{N}(1)$ & $101.3(2)$ & $N(2)-\operatorname{In}(1)-N(3)$ & $69.5(2)$ & $\mathrm{C}(2)-\operatorname{In}(1)-\mathrm{N}(3)$ & $94.5(3)$ \\
\hline $\mathrm{C}(1)-\operatorname{In}(1)-\mathrm{N}(3)$ & $94.0(2)$ & $\mathrm{N}(1)-\operatorname{In}(1)-\mathrm{N}(3)$ & $140.96(19)$ & $\mathrm{N}(5)-\operatorname{In}(2)-\mathrm{C}(14)$ & $112.7(3)$ & $N(5)-\operatorname{In}(2)-C(13)$ & $119.5(2)$ \\
\hline$C(14)-\operatorname{In}(2)-C(13)$ & $127.0(3)$ & $\mathrm{N}(5)-\operatorname{In}(2)-\mathrm{N}(4)$ & $71.5(2)$ & $C(14)-\operatorname{In}(2)-N(4)$ & 106.1(3) & $\mathrm{C}(13)-\operatorname{In}(2)-\mathrm{N}(4)$ & $98.4(2)$ \\
\hline $\mathrm{N}(5)-\operatorname{In}(2)-\mathrm{N}(6)$ & $68.5(2)$ & $\mathrm{C}(14)-\operatorname{In}(2)-\mathrm{N}(6)$ & $95.2(3)$ & $C(13)-\operatorname{In}(2)-N(6)$ & $95.6(2)$ & $N(4)-\operatorname{In}(2)-N(6)$ & $139.5(2)$ \\
\hline \multicolumn{8}{|l|}{$6 \cdot \mathrm{C}_{7} \mathrm{H}_{8}$} \\
\hline $\operatorname{In}(1)-O(1)$ & $2.136(4)$ & $\operatorname{In}(1)-N(2)$ & $2.167(5)$ & $\operatorname{In}(1)-\mathrm{N}(1)$ & $2.334(5)$ & $\mathrm{In}(1)-\mathrm{Cl}(1)$ & $2.434(2)$ \\
\hline $\mathrm{In}(1)-\mathrm{Cl}(1)$ & $2.519(2)$ & $\operatorname{In}(2)-N(5)$ & $2.146(5)$ & $\operatorname{In}(2)-O(1)$ & $2.175(4)$ & $\operatorname{In}(2)-N(4)$ & $2.366(5)$ \\
\hline $\operatorname{In}(2)-\mathrm{Cl}(3)$ & $2.462(2)$ & $\operatorname{In}(2)-\mathrm{Cl}(4)$ & $2.4750(14)$ & & & & \\
\hline $\mathrm{O}(1)-\operatorname{In}(1)-\mathrm{N}(2)$ & $97.5(2)$ & $\mathrm{O}(1)-\mathrm{In}(1)-\mathrm{N}(1)$ & $156.9(2)$ & $\mathrm{N}(2)-\operatorname{In}(1)-\mathrm{N}(1)$ & $78.7(2)$ & $\mathrm{O}(1)-\mathrm{In}(1)-\mathrm{Cl}(1)$ & $106.64(10)$ \\
\hline $\mathrm{N}(2)-\mathrm{In}(1)-\mathrm{Cl}(1)$ & $102.8(1)$ & $\mathrm{N}(1)-\operatorname{In}(1)-\mathrm{Cl}(1)$ & $96.4(1)$ & $\mathrm{O}(1)-\mathrm{In}(1)-\mathrm{Cl}(2)$ & $84.7(1)$ & $\mathrm{N}(2)-\operatorname{In}(1)-\mathrm{Cl}(2)$ & $154.2(1)$ \\
\hline $\mathrm{N}(1)-\operatorname{In}(1)-\mathrm{Cl}(2)$ & $89.2(1)$ & $\mathrm{Cl}(1)-\mathrm{In}(1)-\mathrm{Cl}(2)$ & $101.14(6)$ & $\mathrm{N}(5)-\operatorname{In}(2)-\mathrm{O}(1)$ & $96.9(2)$ & $N(5)-\operatorname{In}(2)-N(4)$ & $77.6(2)$ \\
\hline $\mathrm{O}(1)-\operatorname{In}(2)-\mathrm{N}(4)$ & $161.3(2)$ & $\mathrm{N}(5)-\operatorname{In}(2)-\mathrm{Cl}(3)$ & $98.7(1)$ & $\mathrm{O}(1)-\mathrm{In}(2)-\mathrm{Cl}(3)$ & $98.2(1)$ & $\mathrm{N}(4)-\operatorname{In}(2)-\mathrm{Cl}(3)$ & $100.4(1)$ \\
\hline $\mathrm{N}(5)-\operatorname{In}(2)-\mathrm{Cl}(4)$ & $163.8(1)$ & $\mathrm{O}(1)-\operatorname{In}(2)-\mathrm{Cl}(4)$ & $84.7(1)$ & $\mathrm{N}(4)-\operatorname{In}(2)-\mathrm{Cl}(4)$ & $95.8(1)$ & $\mathrm{Cl}(3)-\operatorname{In}(2)-\mathrm{Cl}(4)$ & $97.03(6)$ \\
\hline $\operatorname{In}(1)-O(1)-\operatorname{In}(2)$ & $108.6(2)$ & & & & & & \\
\hline
\end{tabular}




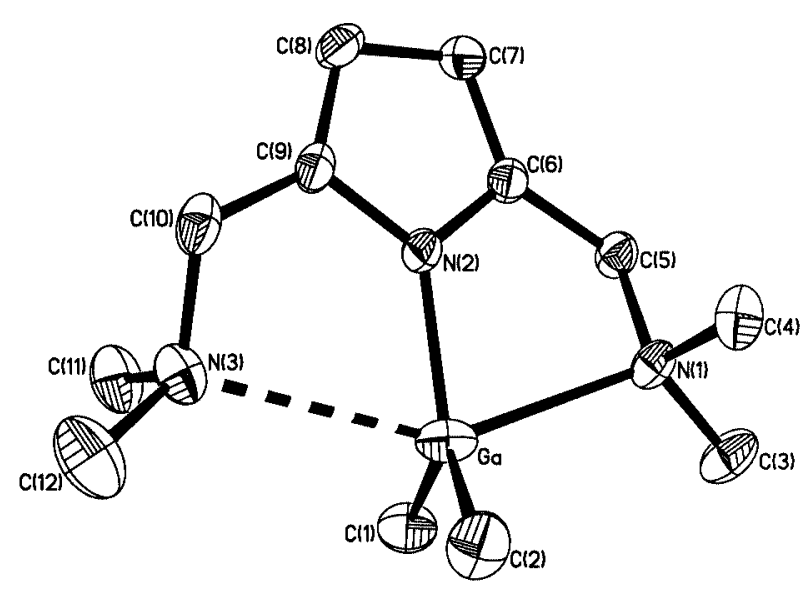

Figure 1. ORTEP diagram of complex 3; thermal ellipsoids at the $50 \%$ probability level and hydrogen atoms are omitted for clarity

by $33.32^{\circ}$ due to the geometrical constraints of the two fused five-membered rings. It is noteworthy that the $\mathrm{N}(1)-\mathrm{Ga}$ and $\mathrm{N}(3)-\mathrm{Ga}$ bond distances of 2.307(2) and $2.736(2) \AA$, respectively, are significantly different. The unit cell of $\mathbf{4}$ contains two independent molecules and the structure of one of these is shown in Figure 2. The structure of 4 is very similar to that of complex 3 . However, the difference of $0.14 \AA$ in the metal-to-axial-nitrogen bond lengths $\operatorname{In}(1)-\mathrm{N}(1)[2.519(5) \AA]$ and $\operatorname{In}(1)-\mathrm{N}(3)[2.661(6) \AA]$ is smaller in $\mathbf{4}$ than in the corresponding gallium species. This is consistent with the larger atomic radius of indium. The axial angle, $\mathrm{N}(1)-\mathrm{In}-\mathrm{N}(3)\left[140.96(19)^{\circ}\right]$, deviates from linearity by $39.04^{\circ}$ due to the steric constraints imposed by the two fused five-membered rings.

Crystals of complex $\mathbf{6}$ were obtained by dissolving $\mathbf{2}$ in toluene and cooling to $-20{ }^{\circ} \mathrm{C}$. The reaction of $\mathbf{2}$ with moisture was effected by slowly exposing the solution to air occasionally. This caused crystals of $\mathbf{6}$ to appear in the flask. The crystals were collected and characterized by ${ }^{1} \mathrm{H}$ NMR spectroscopy and a single-crystal X-ray diffraction study. Details of the data collection for complex $\mathbf{6}$ are sum-

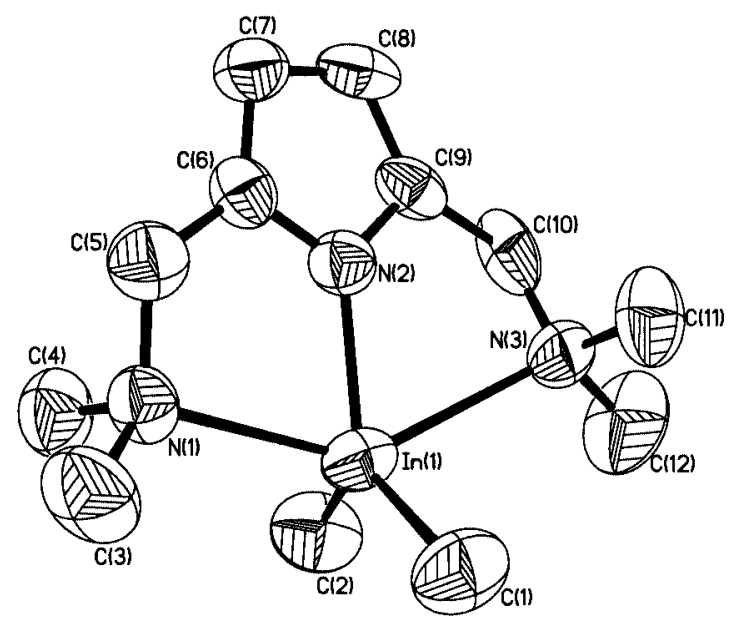

Figure 2. ORTEP diagram of complex 4; thermal ellipsoids are at the $50 \%$ probability level and hydrogen atoms are omitted for clarity marized in Table 2 with selected bond lengths and angles listed in Table 1. The ORTEP diagram of $\mathbf{6}$ is shown in Figure 3. The structure of $\mathbf{6}$ can be described as corner-sharing bis(square-pyramidal), in which the oxygen atom acts as the corner atom with $\mathrm{Cl}(1)$ and $\mathrm{Cl}(3)$ occupying the apical positions. A view of the coordination spheres of the two indium centers is shown in Figure 4, where the two square planes are joined by the oxygen atom. The $\operatorname{In}(1)$ and $\operatorname{In}(2)$ atoms are displaced from the planes defined by $\mathrm{N}(1)-\mathrm{N}(2)-\mathrm{O}(1)-\mathrm{Cl}(2)$ and $\mathrm{N}(4)-\mathrm{N}(5)-\mathrm{O}(1)-\mathrm{Cl}(4)$ by 0.4717 and $0.3389 \AA$, respectively. The question has been raised as to whether the oxygen-containing bridging groups should be viewed as water molecules or dianionic oxo groups. Although the hydrogen atoms of the bridging group were not found either in the ${ }^{1} \mathrm{H}$ NMR spectrum or in the Xray crystal structure, three points support the water-bridged formulation for the dinuclear indium complex: (1) In both 4 and $\mathbf{6}$, both pyrrolyl groups exist as $\sigma$-coordinated ligands with similar In $-\mathrm{N}$ distances [2.108(5) vs. $2.17 \AA$ A]. Furthermore, accommodation of the two methyl groups results in an oxidation state of +3 for the In center. These data suggest that the oxygen atom is coordinated to the indium

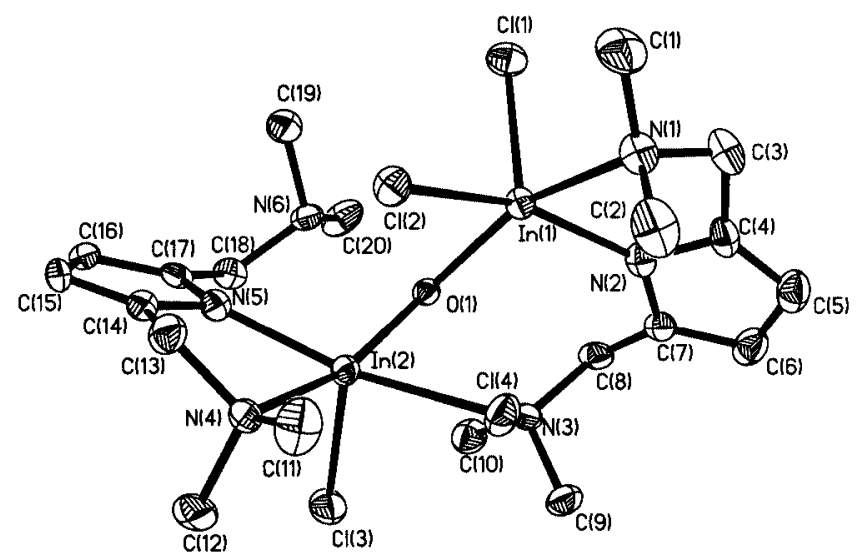

Figure 3. ORTEP diagram of complex 6; thermal ellipsoids are at the $50 \%$ probability level and hydrogen atoms are omitted for clarity

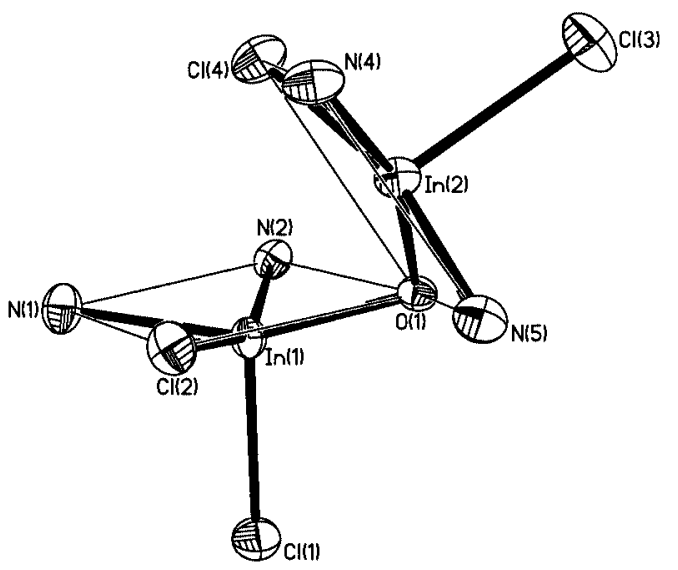

Figure 4. View of the coordination spheres of complex 6 showing only atoms coordinated to the indium atom; thermal ellipsoids are at the $50 \%$ probability level 
atom via a lone pair of electrons. (2) The bond angle subtended by $\operatorname{In}(2)-\mathrm{O}(1)-\operatorname{In}(1)$ in complex 6 is $108.6(2)^{\circ}$, which is very close to the $\mathrm{sp}^{3}$ bonding angle of 109.28 . (3) Finally, an IR spectrum of $\mathbf{6}$ supports the existence of the bridged $\mathrm{H}_{2} \mathrm{O}$ molecule, since a broad characteristic $\mathrm{OH}$ stretching peak was observed at $3460 \mathrm{~cm}^{-1}$. Oxygen-atombridged dinuclear indium complexes have been observed often, ${ }^{[28-30]}$ however, water-bridged diindium complexes have not been reported.

\section{Experimental Section}

General Procedures: All reactions were performed under dry nitrogen using standard Schlenk techniques or a glove box. Toluene, diethyl ether, and tetrahydrofuran were dried by heating to reflux in the presence of sodium benzophenone ketyl. $\mathrm{CH}_{2} \mathrm{Cl}_{2}$ was dried with $\mathrm{P}_{2} \mathrm{O}_{5}$. All solvents were distilled and stored under nitrogen in solvent reservoirs containing $4-\AA$ molecular sieves. ${ }^{1} \mathrm{H}$ and ${ }^{13} \mathrm{C}$ NMR spectra were recorded with a Bruker AC 200 spectrometer. Chemical shifts for ${ }^{1} \mathrm{H}$ and ${ }^{13} \mathrm{C}$ spectra were recorded in ppm relative to the residual protons of the solvent or the ${ }^{13} \mathrm{C}$ resonances of the deuterated solvent: $\mathrm{CDCl}_{3}(\delta=7.24,77.0 \mathrm{ppm}), \mathrm{C}_{6} \mathrm{D}_{6}(\delta=$ $7.15,128.0 \mathrm{ppm})$, or $\mathrm{CD}_{2} \mathrm{Cl}_{2}(\delta=5.24,54.0 \mathrm{ppm})$. Elemental analyses were performed with a Heraeus CHN-OS Rapid Elemental Analyzer at the Instrument Center, NCHU. $\left[\mathrm{C}_{4} \mathrm{H}_{3} \mathrm{~N}\left(\mathrm{CH}_{2} \mathrm{NMe}_{2}\right)_{2}\right.$ 2,5] and $\mathrm{Li}\left[\mathrm{C}_{4} \mathrm{H}_{2} \mathrm{~N}\left(\mathrm{CH}_{2} \mathrm{NMe}_{2}\right)_{2}\right.$-2,5] were prepared according to previously reported procedures. ${ }^{[23-25]} \mathrm{InCl}_{3}$ (Strem) and MeLi (Aldrich) were used as received.

$\left[\left\{\mathbf{C}_{\mathbf{4}} \mathbf{H}_{\mathbf{2}} \mathbf{N}\left(\mathbf{C H}_{\mathbf{2}} \mathbf{N M e}_{\mathbf{2}}\right)_{\mathbf{2}} \mathbf{- 2}, \mathbf{5}\right\} \mathbf{G a C l}_{\mathbf{2}}\right]$ (1): A $100-\mathrm{mL}$ Schlenk flask was charged with a solution of $\mathrm{GaCl}_{3}(5.0 \mathrm{~g}, 28.57 \mathrm{mmol})$ in diethyl ether $(30 \mathrm{~mL})$. This solution was added dropwise to a suspension of $\mathrm{Li}\left[\mathrm{C}_{4} \mathrm{H}_{2} \mathrm{~N}\left(\mathrm{CH}_{2} \mathrm{NMe}_{2}\right)-2,5\right](5.34 \mathrm{~g}, 28.57 \mathrm{mmol})$ in diethyl ether (20 mL) with stirring at $-78{ }^{\circ} \mathrm{C}$. The mixture was allowed to warm to room temperature and stirred for $5 \mathrm{~h}$. The resultant suspension was filtered through Celite. The filtrate was concentrated to dryness and the resultant solid was recrystallized from diethyl ether to afford $1(9.0 \mathrm{~g}, 98 \%) .{ }^{1} \mathrm{H} \mathrm{NMR}\left(\mathrm{CDCl}_{3}\right): \delta=2.52(\mathrm{~s}, 12 \mathrm{H}, \mathrm{NMe})$, 3.63(s, $\left.4 \mathrm{H}, \mathrm{CH}_{2} \mathrm{~N}\right), 5.95(\mathrm{~s}, 2 \mathrm{H}) \mathrm{ppm} .{ }^{13} \mathrm{C} \mathrm{NMR}\left(\mathrm{CDCl}_{3}\right): \delta=$ $47.0\left(\mathrm{q}, J_{\mathrm{C}, \mathrm{H}}=136 \mathrm{~Hz}, \mathrm{~N} M e_{2}\right), 58.8\left(\mathrm{t}, J_{\mathrm{C}, \mathrm{H}}=139 \mathrm{~Hz}, C_{2} \mathrm{~N}\right)$, $105.2\left(\mathrm{~d}, J_{\mathrm{C}, \mathrm{H}}=167 \mathrm{~Hz}\right), 128.0$ (s) ppm. $\mathrm{C}_{10} \mathrm{H}_{18} \mathrm{Cl}_{2} \mathrm{GaN}_{3}(320.90)$ : calcd. C 37.43, H 5.65, N 13.09; found C 36.93, H 5.68, N 12.55.

$\left[\left\{\mathrm{C}_{4} \mathrm{H}_{2} \mathbf{N}\left(\mathrm{CH}_{2} \mathrm{NMe}_{2}\right)_{2}-\mathbf{2}, \mathbf{5}\right\} \mathbf{I n C l}_{\mathbf{2}}\right]$ (2): This complex was prepared in a similar way to that described for $\mathbf{1}$, starting from $\mathrm{InCl}_{3}(3.0 \mathrm{~g}$, $13.6 \mathrm{mmol})$ and $\mathrm{Li}\left[\mathrm{C}_{4} \mathrm{H}_{2} \mathrm{~N}\left(\mathrm{CH}_{2} \mathrm{NMe}_{2}\right)-2,5\right]$ (2.53 g, $\left.13.6 \mathrm{mmol}\right)$. Yield: $4.03 \mathrm{~g}(81 \%) .{ }^{1} \mathrm{H}$ NMR $\left(\mathrm{CDCl}_{3}\right): \delta=2.54$ (s, $\left.12 \mathrm{H}, \mathrm{NMe}\right)_{2}$, $3.65\left(\mathrm{~s}, 4 \mathrm{H}, \mathrm{CH}_{2} \mathrm{~N}\right), 5.99$ (s, $\left.2 \mathrm{H}\right) \mathrm{ppm} .{ }^{13} \mathrm{C} \mathrm{NMR}\left(\mathrm{CDCl}_{3}\right): \delta=$ $46.5\left(\mathrm{q}, J_{\mathrm{C}, \mathrm{H}}=137 \mathrm{~Hz}, \mathrm{~N} M e_{2}\right), 59.3\left(\mathrm{t}, J_{\mathrm{C}, \mathrm{H}}=138 \mathrm{~Hz}, C_{2} \mathrm{~N}\right)$, $106.4\left(\mathrm{~d}, J_{\mathrm{C}, \mathrm{H}}=167 \mathrm{~Hz}\right), 129.5$ (s) ppm. $\mathrm{C}_{10} \mathrm{H}_{18} \mathrm{Cl}_{2} \mathrm{InN}_{3}$ (365.99): calcd. C 32.82, H 4.96, N 11.48; found C 32.26, H 4.54, N 10.92.

$\left[\left\{\mathrm{C}_{4} \mathrm{H}_{2} \mathbf{N}\left(\mathrm{CH}_{2} \mathrm{NMe}_{2}\right)_{2}-\mathbf{2}, \mathbf{5}\right\} \mathbf{G a M e}_{2}\right]$ (3): A 50-mL Schlenk flask was charged with diethyl ether $(20 \mathrm{~mL})$ and $\mathbf{1}(2.0 \mathrm{~g}, 6.23 \mathrm{mmol})$ and the resultant solution was cooled to $-78{ }^{\circ} \mathrm{C}$. To this solution was added MeLi (1.4 $\mathrm{M}$ in diethyl ether, $4.45 \mathrm{~mL}, 12.5 \mathrm{mmol}$ ) via syringe. The mixture was stirred at room temperature for $5 \mathrm{~h}$, and the resultant suspension was heated to reflux for $30 \mathrm{~min}$ and filtered through Celite. The filtrate was concentrated to dryness affording 3 in $75 \%$ yield $(1.30 \mathrm{~g}) .{ }^{1} \mathrm{H}$ NMR $\left(\mathrm{CDCl}_{3}\right): \delta=-0.37(\mathrm{~s}, 6 \mathrm{H}$, $\mathrm{GaMe}), 2.29$ (s, $\left.12 \mathrm{H}, \mathrm{N} M e_{2}\right), 3.48\left(\mathrm{~s}, 4 \mathrm{H}, \mathrm{CH}_{2} \mathrm{~N}\right), 5.89$ (s, $\left.2 \mathrm{H}\right)$ ppm. ${ }^{13} \mathrm{C} \mathrm{NMR}\left(\mathrm{CDCl}_{3}\right): \delta=-9.32\left(\mathrm{q}, J_{\mathrm{C}, \mathrm{H}}=121 \mathrm{~Hz}\right), 45.9(\mathrm{q}$, $\left.J_{\mathrm{C}, \mathrm{H}}=137 \mathrm{~Hz}, \mathrm{~N} M e_{2}\right), 58.9\left(\mathrm{t}, J_{\mathrm{C}, \mathrm{H}}=136 \mathrm{~Hz}, \mathrm{CH}_{2} \mathrm{~N}\right), 103.0(\mathrm{~d}$, $J_{\mathrm{C}, \mathrm{H}}=163 \mathrm{~Hz}$ ), 131.9 (s) ppm. $\mathrm{C}_{12} \mathrm{H}_{24} \mathrm{GaN}_{3}$ (280.06): calcd. C
51.46, H 8.64, N 15.00; found C 49.802, H 8.036, N 14.51. The error in the elemental analysis may be due to traces of $\mathrm{LiBr}$ in the final product.

$\left[\left\{\mathrm{C}_{4} \mathrm{H}_{2} \mathrm{~N}\left(\mathrm{CH}_{2} \mathrm{NMe}_{2}\right)_{2}-2,5\right\} \mathrm{InMe}_{2}\right]$ (4) and $\left[\left\{\mathrm{C}_{4} \mathrm{H}_{2} \mathrm{~N}\left(\mathrm{CH}_{2} \mathrm{NMe}_{2}\right)_{2}-\right.\right.$ $\mathbf{2 , 5}\} \mathbf{I n B u}_{2}$ ] (5): A similar procedure described for the preparation of complexe $\mathbf{3}$ was applied for the preparation of $\mathbf{4}$ and $\mathbf{5}$. The yield of 4 was $61 \%(0.54 \mathrm{~g}$, based on $1.0 \mathrm{~g}$ of 2$) .{ }^{1} \mathrm{H} \mathrm{NMR}\left(\mathrm{CDCl}_{3}\right): \delta=$ -0.31 (s, $6 \mathrm{H}, \mathrm{In} M e$ ), 2.31 (s, $12 \mathrm{H}, \mathrm{N} M e_{2}$ ), 3.47 (s, $4 \mathrm{H}, \mathrm{CH}_{2} \mathrm{~N}$ ), $5.91(\mathrm{~s}, 2 \mathrm{H}) \mathrm{ppm} .{ }^{13} \mathrm{C} \mathrm{NMR}\left(\mathrm{CDCl}_{3}\right): \delta=-10.6$ (q, $J_{\mathrm{C}, \mathrm{H}}=$ $126 \mathrm{~Hz}), 46.1\left(\mathrm{q}, J_{\mathrm{C}, \mathrm{H}}=135 \mathrm{~Hz}, \mathrm{~N} M e_{2}\right), 59.4\left(\mathrm{t}, J_{\mathrm{C}, \mathrm{H}}=135 \mathrm{~Hz}\right.$, $\left.\mathrm{CH}_{2} \mathrm{~N}\right), 103.0\left(\mathrm{~d}, J_{\mathrm{C}, \mathrm{H}}=164 \mathrm{~Hz}\right), 131.9(\mathrm{~s})$ ppm. $\mathrm{C}_{12} \mathrm{H}_{24} \mathrm{InN}_{3}$ (325.16): calcd. C 44.33, H 7.44, N 12.92; found C 44.92, H 6.96, $\mathrm{N} \mathrm{12.65}$. For 5 the yield was $65 \%(0.73 \mathrm{~g}$, based on $1.0 \mathrm{~g}$ of 2$)$ of a brown viscous liquid after removing all volatiles. Due to the viscosity of complex $\mathbf{5}$, it could not be purified by recrystallization or distillation. ${ }^{1} \mathrm{H} \mathrm{NMR}\left(\mathrm{CDCl}_{3}\right): \delta=0.66(\mathrm{t}, 4 \mathrm{H}$, $\mathrm{InCH}_{2} \mathrm{CH}_{2} \mathrm{CH}_{2} \mathrm{CH}_{3}$ ), 0.89 (t, $6 \mathrm{H}, \mathrm{InCH}_{2} \mathrm{CH}_{2} \mathrm{CH}_{2} \mathrm{CH}_{3}$ ), 1.31 (m, $\left.4 \mathrm{H}, \mathrm{InCH}_{2} \mathrm{CH}_{2} \mathrm{CH}_{2} \mathrm{CH}_{3}\right), 1.57$ (m, $\left.4 \mathrm{H}, \mathrm{InCH}_{2} \mathrm{CH}_{2} \mathrm{CH}_{2} \mathrm{CH}_{3}\right), 2.34$ (s, $\left.12 \mathrm{H}, \mathrm{NMe} e_{2}\right), 3.45\left(\mathrm{~s}, 4 \mathrm{H}, \mathrm{CH}_{2} \mathrm{~N}\right), 5.91(\mathrm{~s}, 2 \mathrm{H}) \mathrm{ppm} .{ }^{13} \mathrm{C} \mathrm{NMR}$ $\left(\mathrm{CDCl}_{3}\right): \delta=13.2\left(\mathrm{t}, J_{\mathrm{C}, \mathrm{H}}=140 \mathrm{~Hz}\right), 13.7\left(\mathrm{q}, J_{\mathrm{C}, \mathrm{H}}=123 \mathrm{~Hz}\right)$, $28.8\left(\mathrm{t}, J_{\mathrm{C}, \mathrm{H}}=125 \mathrm{~Hz}\right), 30.3\left(\mathrm{t}, J_{\mathrm{C}, \mathrm{H}}=128 \mathrm{~Hz}\right), 46.8\left(\mathrm{q}, J_{\mathrm{C}, \mathrm{H}}=\right.$ $137 \mathrm{~Hz}, \mathrm{NMe}), 60.0\left(\mathrm{t}, J_{\mathrm{C}, \mathrm{H}}=135 \mathrm{~Hz}, \mathrm{CH}_{2} \mathrm{~N}\right), 103.0\left(\mathrm{~d}, J_{\mathrm{C}, \mathrm{H}}=\right.$ $164 \mathrm{~Hz}), 132.7$ (s). No elemental analysis was performed due to a small amount of impurity present in the product.

$\left[\left\{\left[\mathrm{C}_{4} \mathrm{H}_{2} \mathrm{~N}\left(\mathrm{CH}_{2} \mathrm{NMe}_{2}\right)_{2}-\mathbf{2 , 5}\right] \mathrm{InCl}_{2}\right\}_{2}\left(\boldsymbol{\mu}-\mathrm{OH}_{2}\right)\right]$ (6): The same procedure was applied for the preparation of $\mathbf{6}$ as that used to synthesize $\mathbf{2}$, with the exception that during recrystallization of complex $\mathbf{2}$ from a toluene solution at $-20{ }^{\circ} \mathrm{C}$ the Schlenk flask was periodically opened to air. This resulted in the deposition of $\mathbf{6}$ on the bottom of the flask $\left(1.03 \mathrm{~g}, 13 \%\right.$, based on $5 \mathrm{~g}$ of $\left.\mathrm{InCl}_{3}\right) .{ }^{1} \mathrm{H} \mathrm{NMR}$ $\left(\mathrm{CD}_{2} \mathrm{Cl}_{2}\right): \delta=2.50$ (br. s, $6 \mathrm{H}, \mathrm{NMe}$ ), 2.59 (br. s, $6 \mathrm{H}, \mathrm{NMe}$ ), 2.84 (br. s, $12 \mathrm{H}, \mathrm{NMe}$ ), $3.16\left(\mathrm{~d}, 4 \mathrm{H}, \mathrm{CH}_{2} \mathrm{~N}\right), 3.70\left(\mathrm{~d}, 4 \mathrm{H}, \mathrm{CH}_{2} \mathrm{~N}\right)$, $4.56\left(\mathrm{~d}, 4 \mathrm{H}, \mathrm{CH}_{2} \mathrm{~N}\right), 4.72\left(\mathrm{~d}, 4 \mathrm{H}, \mathrm{CH}_{2} \mathrm{~N}\right), 6.01(\mathrm{~d}, 2 \mathrm{H}), 6.26(\mathrm{~d}$, $2 \mathrm{H}) \mathrm{ppm} .{ }^{13} \mathrm{C} \mathrm{NMR}\left(\mathrm{CD}_{2} \mathrm{Cl}_{2}\right): 47.8\left(\mathrm{q}, J_{\mathrm{C}, \mathrm{H}}=136 \mathrm{~Hz}, \mathrm{NMe} e_{2}\right.$, $49.6\left(\mathrm{q}, J_{\mathrm{C}, \mathrm{H}}=135 \mathrm{~Hz}, \mathrm{~N} M e_{2}\right), 50.2\left(\mathrm{q}, J_{\mathrm{C}, \mathrm{H}}=135 \mathrm{~Hz}, \mathrm{~N} M e_{2}\right)$, $60.6\left(\mathrm{t}, J_{\mathrm{C}, \mathrm{H}}=139 \mathrm{~Hz}, \mathrm{CH}_{2} \mathrm{~N}\right), 61.3\left(\mathrm{t}, J_{\mathrm{C}, \mathrm{H}}=145 \mathrm{~Hz}, \mathrm{CH}_{2} \mathrm{~N}\right)$, $106.3\left(\mathrm{~d}, J_{\mathrm{C}, \mathrm{H}}=167 \mathrm{~Hz}\right), 114.9\left(\mathrm{~d}, J_{\mathrm{C}, \mathrm{H}}=164 \mathrm{~Hz}\right), 122.5(\mathrm{~s}), 136.0$ (s). A small amount of complex 2 was present in $\mathbf{6}$ (less than $3 \%$ by ${ }^{1} \mathrm{H}$ NMR spectroscopy), which prevented a reasonable elemental analysis from being obtained.

X-ray Structure Determination of Complexes 3, 4, and 6: Crystals were mounted on a glass fiber using epoxy resin and transferred to the goniostat. Data collections were preformed at $150 \mathrm{~K}$ under liquid nitrogen vapor for complexes $\mathbf{3}$ and $\mathbf{6}$ and at $293 \mathrm{~K}$ for complex 4. Data were collected with a Bruker SMART CCD diffractometer with graphite-monochromated Mo- $K_{\alpha}$ radiation. Structural determinations were carried out using the SHELXTL package of programs. All refinements were carried out by the full-matrix leastsquares method using anisotropic displacement parameters for all non-hydrogen atoms. All the hydrogen atoms were placed in calculated positions. The crystal data are summarized in Table 2. CCDC-185057 and -185059 contain the supplementary crystallographic data for this paper. These data can be obtained free of charge at www.ccdc.cam.ac.uk/conts/retrieving.html [or from the Cambridge Crystallographic Data Centre, 12 Union Road, Cambridge CB2 1EZ, UK; Fax: (internat.) + 44-1223/336-033; E-mail: deposit@ccdc.cam.ac.uk].

\section{Acknowledgments}

We thank the National Science Council of Taiwan for financial support and the National Center for High Performance Computing 
Table 2. Summary of crystallographic data for compounds $\mathbf{3}, \mathbf{4}$, and $\mathbf{6}$

\begin{tabular}{|c|c|c|c|}
\hline & 3 & 4 & 6 \\
\hline Empirical formula & $\mathrm{C}_{12} \mathrm{H}_{24} \mathrm{GaN}_{3}$ & $\mathrm{C}_{24} \mathrm{H}_{48} \operatorname{In} 2 \mathrm{~N}_{6}$ & $\mathrm{C}_{27} \mathrm{H}_{46} \mathrm{Cl}_{4} \mathrm{In}_{2} \mathrm{~N}_{6} \mathrm{O}$ \\
\hline Formula mass & 280.06 & 650.32 & 842.14 \\
\hline Temperature $[\mathrm{K}]$ & $150(1)$ & $293(2)$ & $150(1)$ \\
\hline Crystal system & orthorhombic & monoclinic & monoclinic \\
\hline Space group & Pbca & $C 2 / c$ & $P 2{ }_{1} / c$ \\
\hline$a[\AA]$ & $12.1751(6)$ & $27.4334(17)$ & $9.3723(1)$ \\
\hline$b[\AA]$ & $15.2278(7)$ & $9.1830(6)$ & $17.6586(3)$ \\
\hline$c[\AA]$ & $15.6050(7)$ & $27.5320(17)$ & $21.9571(2)$ \\
\hline$\beta\left[\left[^{\circ}\right]\right.$ & 90 & $117.23(1)$ & $92.704(1)$ \\
\hline Volume $\left[\AA^{3}\right] / Z$ & $2893.2(2) / 8$ & $6173.1(7) / 8$ & $3629.89(8) / 4$ \\
\hline Density (calcd.) $\left[\mathrm{Mg} / \mathrm{m}^{3}\right]$ & 1.286 & 1.399 & 1.541 \\
\hline Absorption coefficient $\left[\mathrm{mm}^{-1}\right]$ & 1.884 & 1.514 & 1.594 \\
\hline$F(000)$ & 1184 & 2656 & 1696 \\
\hline Crystal size [mm] & $0.50 \times 0.40 \times 0.10$ & $0.36 \times 0.31 \times 0.07$ & $0.20 \times 0.10 \times 0.10$ \\
\hline$\theta$ range $\left[{ }^{\circ}\right]$ & 2.51 to 27.50 & 1.66 to 27.51 & 1.48 to 27.50 \\
\hline No. of reflns. collected & 16753 & 19182 & 20140 \\
\hline No. of indep. reflns. & $3318\left(R_{\mathrm{int}}=0.0375\right)$ & $7066\left(R_{\mathrm{int}}=0.0339\right)$ & $8096\left(R_{\mathrm{int}}=0.08533\right)$ \\
\hline Max./min. trans. & $0.6471 / 0.4120$ & $0.9486 / 0.8740$ & $0.8621 / 0.5674$ \\
\hline No. of data/restraints/params. & $3318 / 0 / 146$ & $7066 / 0 / 297$ & $8095 / 0 / 362$ \\
\hline Goodness of fit on $F^{2}$ & 1.094 & 1.014 & 1.017 \\
\hline Final $R$ indices $[I>2 \sigma(I)], R_{1}{ }^{[a]}$ & 0.0363 & 0.0409 & 0.0581 \\
\hline$w R_{2}{ }^{[\mathrm{b}]}$ & 0.0754 & 0.0830 & 0.1007 \\
\hline$R$ indices (all data), $R_{1}^{[\mathrm{a}]}$ & 0.0463 & 0.1177 & 0.1045 \\
\hline$w R_{2}{ }^{[\mathrm{b}]}$ & 0.0793 & 0.1137 & 0.1169 \\
\hline Largest diff. peak/hole $\left[\mathrm{e} \cdot \AA^{-3}\right]$ & $0.674 /-0.615$ & $0.765 /-0.739$ & $1.812 /-1.210$ \\
\hline
\end{tabular}

${ }^{[\mathrm{a}]} R_{1}=\Sigma\left|F_{\mathrm{o}}\right|-\left|F_{\mathrm{c}}\right| \Sigma\left|F_{\mathrm{o}}\right|{ }^{[\mathrm{b}]} w R_{2}=\left\{\Sigma\left[w\left(F_{\mathrm{o}}{ }^{2}-F_{\mathrm{c}}{ }^{2}{ }^{2}\right] / \Sigma\left[w\left(F_{\mathrm{o}}{ }^{2}\right)^{2}\right]^{1 / 2}\right\}\right.$.

for databank searches. We also thank Dr. Darin Tiedtke for helpful discussions and for proofreading this manuscript.

[1] H. Yamamoto (Ed.), Lewis Acids in Organic Synthesis, WileyVCH, Weiheim, 2000.

[2] M. Bochmann, D. M. Dawson, Angew. Chem. Int. Ed. Engl. 1996, 35, 2226-2228.

[3] D. A. Atwood, J. A. Jegier, D. Rutherford, J. Am. Chem. Soc. 1995, 117, 6779-6780.

[4] M. P. Coles, R. F. Jordan, J. Am. Chem. Soc. 1997, 119, 8125-8126.

[5] S. Araki, T. Kamei, T. Hirashita, H. Yamamura, M. Kawai, Org. Lett. 2000, 2, 847-849.

[6] N. Fujiwara, Y. Yamamoto, J. Org. Chem. 1997, 62, $2318-2319$.

[7] B. C. Ranu, A. Majee, Chem. Commun. 1997, 1225-1226.

${ }^{[8]}$ P. Cintas, Synlett 1995, 1087-1096.

[9] L. A. Paquette, R. R. Rothhaar, M. Issac, L. M. Rogers, R. D. Rogers, J. Org. Chem. 1998, 63, 5463-5472.

${ }^{[10]}$ T. H. Chan, Y. Yang, J. Am. Chem. Soc. 1999, 121, 3228-3229.

${ }^{[11]}$ C. J. Li, T. H. Chan, Organic Reactions in Aqueous Media, John Wiley \& Sons, New York, 1997.

${ }^{[12]}$ C. D. Abernethy, M. L. Cole, C. Jones, Organometallics 2000, 19, $4852-4857$.

${ }^{[13]}$ L. A. Mîinea, S. Suh, D. M. Hoffman, Inorg. Chem. 1999, 38, 4447-4454.

${ }^{[14]}$ A. M. Arif, A. H. Cowley, T. M. Elkins, R. A. Jones, J. Chem. Soc., Chem. Commun. 1986, 1776-1777.

${ }^{[15]}$ Y. Zhou, D. S. Richeson, Organometallics 1995, 14, $3558-3561$.
[16] J. T. Leman, H. A. Roman, A. R. Barron, Organometallics 1993, 12, 2986-2990.

[17] Y. Zhou, D. S. Richeson, Inorg. Chem. 1996, 35, 1423-1424.

[18] J.-H. Park, P. O'Brien, A. J. P. White, D. J. Williams, Inorg. Chem. 2001, 40, 3629-3631.

${ }^{[19]}$ S. Suh, D. M. Hoffman, J. Am. Chem. Soc. 2000, 122, 9396-9404.

${ }^{[20]}$ C. J. Olazabal, F. P. Gabbai, A. H. Cowley, Organometallics 1994, 13, 421-423.

${ }^{[21]}$ M. Stender, U. Segerer, J. Sieler, E. Hey-Hawkins, Z. Anorg. Allg. Chem. 1998, 624, 85-90.

${ }^{[22]}$ J.-H. Huang, H.-J. Chen, J.-C. Chang, C.-C. Zhou, G.-H. Lee, S.-M. Peng, Organometallics 2001, 20, 2647-2650.

[23] J.-C. Chang, C.-H. Hung, J.-H. Huang, Organometallics 2001, $20,4445-4447$.

[24] J.-H. Huang, P.-C. Kao, G.-H. Lee, S.-M. Peng, J. Chin. Chem. Soc. 2000, 47, 1191-1195.

[25] J.-H. Huang, L.-S. Chi, F.-M. Huang, P.-C. Kao, G.-H. Lee, S.-M. Peng, J. Chin. Chem. Soc. 2000, 47, 895-900.

${ }^{[26]}$ W. Herz, K. Dittmer, J. Am. Chem. Soc. 1947, 69, 1698-1700.

${ }^{[27]}$ H. Kim, R. L. Elsenbaumer, Tetrahedron Lett. 1998, 39, 1087-1090.

${ }^{[28]}$ D. C. Bradley, H. Chudzynska, D. M. Frigo, M. B. Hursthouse, M. A. Mazid, J. Chem. Soc., Chem. Commun. 1988, $1258-1259$

${ }^{[29]}$ D. C. Bradley, H. Chudzynska, D. M. Frigo, M. E. Hammond, M. B. Hursthouse, M. A. Mazid, Polyhedron 1990, 9, 719-726.

${ }^{[30]}$ For examples of dianionic O-bridged diindium complexes, see: S. Abram, C. Maichle-Mössmer, U. Abram, Polyhedron 1998, 17, 131-143.

Received July 17, 2002 [I02392] 